DOI 10.15290/cnisk.2017.02.03.11

DR SYLWANA BORSZYŃSKA

orcid.org/0000-0003-2654-2708

Uniwersytet Łódzki

\title{
Życie kobiet w wielkoprzemysłowej Łodzi w latach 1908-1914 - wybrane aspekty, ss. 199
}

\section{Streszczenie}

Autoreferat prezentuje główne założenia rozprawy doktorskiej. Pokazuje przyczyny podjęcia tego tematu badawczego przez Autorkę. Zarysowuje stan badań historii kobiet oraz omawia źródła, jakie zostały wykorzystane w pracy: prasa codzienna $z$ Łodzi z okresu 1908-1914: „Kurier Łódzki”, „Nowy Kurier Łódzki”, „Gazeta Łódzka”, „Nowa Gazeta Łódzka”, „Rozwój”, „Lodzer Zeitung” i „Neue Lodzer Zeitung”, a także prasa feministyczna: „Nowe Słowo” i „Ster”, ponadto materiały archiwalne $z$ Archiwum Państwowego w Łodzi (Akta Łódzkiej Dyrekcji Szkolnej, Kancelarii Prezydialnej, a także Policmajstra miasta Łodzi i Akta miasta Łodzi). Dzięki bogatej bazie źródłowej powstała praca doktorska złożona $z$ trzech rozdziałów, krótko omówionych w autoreferacie. Autorka przedstawiła też ogólne rozważania nad historią kobiet oraz najważniejsze wnioski odnoszące się do ich życia w Łodzi zawarte w dysertacji.

Słowa kluczowe: historia kobiet, wielkoprzemysłowa Łódź, źródła, szanse, zagrożenia, życie kobiet na początku XX w., prasa, archiwum, praca doktorska 


\title{
DOCTORAL DISSERTATION ABSTRACT. THE LIFE OF WOMEN IN HEAVY INDUSTRY LÓDŹ IN 1908-1914 - SELECTED ISSUES
}

\begin{abstract}
The following article is a doctoral dissertation abstract and depicts the main theses of the work. It discusses the reasons why the Author has decided to take up the research topic and evaluates the state of the scientific study on the history of women. The Author of the article comments on the information-rich sources used in the dissertation: daily newspapers issued in Łódź between 1908 and 1914 - "Kurier Łódzki", "Nowy Kurier Łódzki", "Gazeta Łódzka", "Nowa Gazeta Łódzka", "Rozwój", "Lodzer Zeitung", "Neue Lodzer Zeitung", as well as the feminist press such as "Nowe Słowo" and "Ster", and selected archival materials available in the State Archive in Łódź. The doctoral dissertation consists of three chapters which are briefly discussed in this article along with the Author's general reflections on the history of women, and some important conclusions about their lives in Lódź of the early $20^{\text {th }}$ century.

Keywords: the history of women, industrial Łódź, sources, chances, dangers, the life of women in the early $20^{\text {th }}$ century, the press, the archives, $\mathrm{PhD}$ dissertation
\end{abstract}

Zawsze znamy jakieś fakty i znaczące wydarzenia $z$ życia naszych ojców. Wiemy, że byli żołnierzami czy marynarzami, wiemy, że pracowali w tym biurze lub, wprowadzili to prawo. A po naszych matkach, naszych prababkach, cóż po nich pozostało? Nic, tylko tradycja (...) nic, prócz ich imion, dat zaślubin i liczby dzieci, które urodziły ${ }^{1}$.

Virginia Woolf

Powyższy cytat stanowi dobry wstęp do rozważań nad rola kobiet w dziejach, ich miejscem w rodzinie, społeczeństwie czy narodzie. W europejskim kręgu kulturowym nie zastanawiamy się już dziś nad tym, czy kobieta jest w ogóle człowiekiem i czy ma duszę.

1 Cyt. za: A. Kusiak, O historii kobiet [w:] Humanistyka i płeć. Kobiety w poznaniu naukowym wczoraj i dziś, red. E. Pakszys, D. Sobczyńska, Poznań 1997, t. 2, s. 198. 
Uznać to można za wielki postęp w stosunku do wielowiekowych rozważań Ojców Kościoła, filozofów, myślicieli, którzy prowadzili międzynarodowe dyskusje na ten temat i duszy kobiecie odmawiali. Dzisiejsze społeczeństwa idą w stronę coraz większej równości między płciami, co już staje się przedmiotem badań socjologów i psychologów, kulturoznawców i antropologów.

Powyższy temat został podjęty $z$ chęci wypełnienia luki badawczej nad historią kobiet w Łodzi w okresie 1908-1914, a także ukazania relacji łączących łodzianki $z$ miastem $i$ ich najbliższym otoczeniem. Znaczenie miała też chęć wzbogacenia wiedzy historycznej o Łodzi i społeczeństwie. Sądzę, iż sprawiedliwość nakazuje, by na kartach dziejów nie znajdowały się tylko królowe, święte i prostytutki, ale też kobiety z krwi i kości, które swoją pracą fizyczną i społeczna przyczyniały się do rozwoju gospodarki i kultury.

Historia kobiet jest dyscyplina stosunkowo młoda, bowiem akademickie badania nad nia zostały podjęte w latach sześćdziesiątych (Wielka Brytania i Stany Zjednoczone) i siedemdziesiątych XX w. (Francja). Zauważenie nieobecności kobiet w historii i ich milczenia było ważnym czynnikiem, który wpłynął na chęć zmiany i oddania kobietom należnego im miejsca. Choć wcześniej były podejmowane rozmaite studia, to rozwój badań nad historia kobiet w Polsce przypada na początek lat dziewięćdziesiątych XX w.

W dysertacji podjęłam się próby spojrzenia na życie wszystkich kobiet w Łodzi, stawiając sobie za cel znalezienie odpowiedzi na to, jak radziły sobie nie tylko robotnice czy przedstawicielki rodów burżuazyjnych, ale też inteligentki czy zarządzające swoimi interesami, a także nauczycielki, proste szwaczki, praczki i służace. $Z$ tego też powodu temat pracy został zarysowany dość ogólnie, tak by pokazać wszystkie możliwe aspekty życia wspomnianych kobiet. Możliwości te były limitowane przez źródła. Badanie życia intymnego, wewnętrznego, wymaga m.in. pamiętników, wspomnień czy choćby materiałów epistolarnych. Łodzianki nie zostawiły po sobie zbyt wielu źródeł memuarystycznych. Szybkość życia w wielkoprzemysłowym ośrodku, w którym problemy dnia codziennego i kwestie finansowe przeważały nad innymi, wyraźnie nie sprzyjała pozostawianiu po sobie zapisków. Pomimo chęci wniknięcia w każ- 
dy najmniejszy zakamarek domów, mieszkań i dusz łodzianek ich sekretne życie nadal pozostaje zagadka.

Zachowały się natomiast inne źródła. Przede wszystkim wykorzystałam akta $z$ Archiwum Państwowego w Łodzi, akta Łódzkiej Dyrekcji Szkolnej, Kancelarii Prezydialnej, a także Policmajstra miasta Łodzi oraz Akta miasta Łodzi. Materiały te okazały się bardzo przydatne. Kolejnym niezwykle istotnym źródłem była prasa codzienna $z$ Łodzi z okresu 1908-1914, ponieważ ukazywała nastroje opinii publicznej i ja kształtowała ${ }^{2}$. Kwerendzie poddane zostały dzienniki: „Kurier Łódzki”, „Nowy Kurier Łódzki”, „Gazeta Łódzka”, „Nowa Gazeta Łódzka”, „Rozwój”, „Lodzer Zeitung” i „Neue Lodzer Zeitung”, a także prasa feministyczna „Nowe Słowo” i „Ster”. Zdecydowałam się na kwerendę wszystkich dostępnych tytułów łódzkich, by uzyskać możliwie najszerszy obraz stosunków panujących w mieście oraz podejścia do tzw. kwestii kobiecej. Inaczej bowiem sprawy te opisywano w „Rozwoju” ideowo zwiazanym $z$ kręgami narodowymi, a inaczej m.in. w postępowym „Kurierze” i „Gazecie Łódzkiej”.

Dysertacja składa się $z$ trzech rozdziałów, a treści w nich zawarte pogrupowane sa problemowo dla lepszego zrozumienia wywodu. Pierwszy $z$ rozdziałów wprowadza w sytuację w porewolucyjnej Łodzi, problemy ekonomiczne i społeczne. Ukazuje strukturę ludności i strukturę narodową, a także udział kobiet w powyższych. Poza tym charakteryzuje ich sytuację prawna na początku XX w. oraz opisuje życie zawodowe kobiet.

Rozdział drugi ukazuje mankamenty życia w Łodzi, czyli niebezpieczeństwa czyhające na kobiety zarówno w sferze publicznej, jak i prywatnej. Na rozdział składa się też część o złu, które same wyrządzały w powyższych obszarach życia. Opisuje problemy egzystencji kobiet $z$ warstw ubogich (drobnomieszczaństwa i lumpenproletariatu) oraz tych $z$ marginesu społecznego (np. prostytutek).

Ostatnia część dysertacji zajęła najwięcej miejsca w rozważaniach. Została poświęcona szansom i możliwościom, jakie wyni-

2 J. Myśliński, Uwagi o prasie polskiej przełomu XIX i XX wieku jako źródle historycznym, „Rocznik Historii Czasopiśmiennictwa Polskiego” 1974, t. 14, s. 11. 
kały $z$ działalności ruchu kobiecego, a także samego faktu zamieszkiwania jednego $z$ największych ośrodków miejskich ówczesnego Królestwa Polskiego. Dotyka zatem ich działalności w stowarzyszeniach, dobroczynności, porusza kwestię edukacji kobiet i życia naukowego. Ukazuje dostępność rozmaitych udogodnień - salonów fryzjerskich, sklepów $z$ odzieżą damską, kosmetyków, ale też i instytucji dostępnych dla obu płci, m.in. bibliotek, teatrów, kin, muzeów. Ostatni rozdział dotyka również nowoczesnych i klasycznych form spędzania czasu wolnego przez kobiety.

Łódź na początku XX w. była miastem szczególnym, porównywanym do biblijnej ziemi obiecanej czy Manchesteru. Mnogość pejoratywnych opinii o złym mieście przeważała nad tymi pozytywnymi, co także wzmogło moją ciekawość badawcza. Życie łodzianek było silnie splecione $z$ życiem miasta, jego pulsem i biegiem, pośpiechem i gonitwa za pieniędzmi. Przedsiębiorcze łodzianki potrafiły wykorzystywać dobrą koniunkturę, zakładając nowe szkoły lub prowadząc odziedziczone interesy. Możliwość edukacji w stopniu wyższym była przywilejem warstw zamożnych i kobiety nadal trafiały na utrudnienia w tej kwestii. Okres przed I wojną światową zarysował się jednak jako czas, kiedy coraz więcej absolwentek uniwersytetów - mam na myśli lekarki i dentystki - pracowało w Łodzi. Fakt, iż w tym wielkoprzemysłowym ośrodku udało się odnaleźć kobietę-chirurga, był odkryciem niesamowitym, bowiem zjawisko to nie należało do powszechnych. Zarabiały w ten sposób na życie, niosąc pomoc drugiemu człowiekowi, co jak najbardziej kojarzono $z$ kobieca natura. O chęci wejścia w życie społeczne złego miasta świadczyło także zakładanie przez kobiety stowarzyszeń, ale nie tyle już dobroczynnych, co nowoczesnych instytucji o charakterze zawodowym, kulturalnym, samopomocowym czy oświatowym. Kobiety zaczęły też uprawiać sport i skauting, co w XIX w. kojarzono raczej z męskimi zajęciami. Coraz częściej korzystały ze zdobyczy kultury, chodząc do łódzkich teatrów, kin czy bibliotek, biorac udział w ważnych odczytach. Dostęp do powyższych miały kobiety ze wszystkich warstw, jedynie wykształcenie i zarobki miały wpływ na partycypację w szeroko pojętej kulturze. 
Życie w wielkoprzemysłowej Łodzi nie należało do łatwych, ale czy ogólnie życie kobiet na poczattku XX w. do tej kategorii mogło się zaliczać? Odpowiedź wydaje się oczywista, bowiem brak równych szans i praw charakteryzował cały wiek XIX. Życie kobiet w Łodzi naznaczone było wieloma trudnościami i zagrożeniami, ale też nadziejami i szansami. Wszystko zależało od tego, z jakiej warstwy społecznej kobiety pochodziły, jaką miały energię i talenty.

Napływ ludności wiejskiej do Łodzi skutkował przeobrażeniami w obrębie ich tradycyjnego świata wartości, prowadząc nieraz do zachowań przestęppzych lub niemoralnych. Dotyczyło to obu płci. Brak równości i gorsza pozycja społeczna kobiet skutkowały ich bezsilnościa w wielu sytuacjach życiowych. Niektórzy mężczyźni często wykorzystywali swoja przewagę w sposób prymitywny, po prostu stosując przemoc fizyczna i seksualna. Problemy rodzinne i miłosne kobiet żyjących w Łodzi wyłaniaja się $\mathrm{w}$ znacznym wymiarze. Alkoholizm i bieda zwiazana $\mathrm{z}$ kryzysami gospodarczymi i bezrobociem skutkowały napięciami w rodzinach, spędzaniem płodu czy próbami samobójczymi. Co również istotne, rzutowały na agresywne i przestępcze zachowania łodzianek. Dotyczyło to głównie kobiet $z$ nizin społecznych, także pracujacych i posiadajacych niskie uposażenie. W Łodzi jak w soczewce ogniskowały się problemy społeczne wielkich miast. Problem $z$ ubóstwem i koszmarnymi warunkami bytowymi dopełniał obraz zlego miasta. Prostytucja i handel żywym towarem rozwijały się mimo podejmowania prób walki z nimi. Podwójna moralność, o której tyle dyskutowano na przełomie wieków, nadal się utrzymywała, a pracodawcy chętnie wykorzystywali złe położenie służących czy robotnic zależnych od nich i przerażonych możliwością utraty pracy. Życie biedoty - w dusznych i małych pomieszczeniach, bez bieżącej wody i udogodnień, niskiej jakości pożywienie - prowadziło do degradacji i upadku wielu kobiet. Ale niestety realia tego życia były chlebem powszednim dla znakomitej części łodzianek.

Służace marzyły o pracy robotnicy, bo był to awans zarówno społeczny, jak i zarobkowy, ale ciężki los czekał na jedne i na drugie. Tak naprawdę fabryka zamykała przed nimi szansę na dalsza edukację oraz lepsze życie, ale dawała utrzymanie na minimalnym 
poziomie i docenienie w społeczności robotniczej. Brak wykształcenia zamykał jednak kobietom wiele dróg i przypieczętowywał ich los. Bieda i wynikajace $z$ niej deprawacje i patologie to najtragiczniejsze aspekty życia kobiet w Łodzi.

Kobiety $z$ drobnomieszczaństwa i inteligencji miały większe możliwości i w mniejszym stopniu dotykał je syndrom złego miasta. Świadomość zdobyta wraz $z$ wychowaniem i edukacja miały duże znaczenie. Nie wspominając już o kobietach $z$ burżuazji, których było najmniej, a ich życie opływało w dostatki.

W Łodzi to głównie pieniądze decydowały o możliwościach - życiu w luksusie, w otoczeniu dzieł sztuki, wytwornych toalet, przy pełnym dostępie do klasycznych i nowoczesnych form rozrywek i sportu czy zagranicznych peregrynacji. Wizerunek Łodzi jako miasta głębokich kontrastów społecznych potwierdził się w wyniku podjętych badań. Zauważyć bowiem należy dobitnie, iż niesamowita przepaść dzieliła kobiety różnych warstw. Pomimo tego, że mieszkały w jednym mieście, ich życie biegło inaczej. Unifikowały je natomiast takie elementy jak brak praw równych mężczyznom i prokreacja, a także wspólna praca niektórych na rzecz ogółu. Wypada jednak zaznaczyć, że życie w wielkim mieście znacząco różniło się od życia chłopek czy ziemianek na wsi, za co odpowiedzialna była atmosfera postępu i nowoczesności, w której kobiety partycypowały, obojętnie $z$ jakiej warstwy pochodziły. Inna zatem musiała być mentalność chłopki i łodzianki mieszkającej w mieście choćby kilka lat. Życie w Łodzi cechowało się ciagłym pędem i pośpiechem. Czasem w tym zapomnieniu i gonitwie kobiety zapominały o moralności.

Oczywisty był fakt, że ówczesne prawo w pierwszym szeregu stawiało mężczyznę. Ale dyskusje toczone m.in. w łonie sfer rządzących Cesarstwem Rosyjskim nad zmiana praw kobiety zamężnej, których echa docierały na łamy łódzkiej prasy, świadczyły o powolnych zmianach w zakresie prawodawstwa i sytuacji kobiet. Nie bez znaczenia było przyzwolenie na to, by kobiety miały odrębne paszporty czy mogły pracować lub się uczyć bez zgody męża po rozstaniu. Sądzić można, iż w badanym okresie postępowała ewolucja stosunków społecznych. Kobiety powoli zyskiwały coraz więcej praw. 
Wydaje mi się zasadne powiązanie tego faktu $z$ rosnącymi aspiracjami naukowymi i zawodowymi kobiet, i, co najważniejsze, coraz bardziej rozpowszechnianym postulatom ruchu kobiecego. Rósł on w siłę, o czym świadczyły międzynarodowe wiece i spotkania, a także jego ogromne sukcesy w niektórych państwach europejskich.

Cała ta atmosfera zmian oraz zwiększających się dążeń kobiecych w Europie i Stanach Zjednoczonych wyczuwalna była w Królestwie Polskim i nie ominęła nawet prowincjonalnej Łodzi. Badania pokazały, że rzutowała ona w sposób znaczący również na życie kobiet łódzkich. Pierwszym hasłem ruchu emancypacyjnego był równy dostęp do edukacji. Kobiety o ten dostęp walczyły, a zwiększająca się każdego roku liczba prywatnych szkół średnich w Łodzi, mających coraz więcej klas, była tego emanacją. Co więcej, zauważyć należy, iż nie tylko pokazywało wzrastające zainteresowanie dziewcząt edukacją, ale też i odwagę oraz przedsiębiorczość kobiet, które te szkoły prowadziły. Rosnaca liczba chętnych praktykantek, które chciały pracować jako nauczycielki, też nie pozostawała bez znaczenia. Jakkolwiek większym prestiżem cieszyli się nadal w tym zawodzie mężczyźni, to procesu jego feminizacji nie dało się powstrzymać.

Chociaż społeczność łódzka pozostawała konserwatywna, funkcjonujaca $\mathrm{w}$ ramach schematów wytyczonych pochodzeniem społecznym, konwenansami i religia, to powyższe spostrzeżenia mogły wskazywać na powolne zmiany zachodzące w mentalności łodzian oraz na postępujace procesy modernizacyjne i demokratyczne w mieście.

Tama męskiej dominacji nadal trzymała w ryzach rzekę kobiecych dążeń i aspiracji, ale dzięki uporowi i podejmowanym działaniom tama ta zaczęła puszczać, a woda płynąc coraz szerszym strumieniem. Do całkowitej równości kobiety miały jeszcze bardzo długa drogę i - co warto podkreślić - także i dziś nierzadko mówi się o jej braku, mimo że okresy te dzieli przecież ponad 100 lat (sic!). Ale wydaje się, że gdyby nie ta walka, upór, ciężka praca i konsekwencja na przełomie XIX i XX w. proces emancypacji kobiet w Polsce mógłby potoczyć się inaczej lub trwać dłużej. Kobiety $\mathrm{w}$ postulatach ruchu kobiecego odnalazły szansę na lepsze 
życie i droga ewolucji powoli wkraczały w aktywność publiczna, społeczna i zawodowa, wychodząc małymi krokami poza zaklęty krag życia rodzinnego, jakie im przeznaczano w wieku XIX. Poważna zmianę przyniosła I wojna światowa, która ułatwiła kobietom wstęp do sfery publicznej. Wyrazem wcześniejszych działań ruchu kobiecego i wpływu wojny było nadanie kobietom pełni praw obywatelskich 28 listopada 1918 r.

Wszystkie powyższe aspekty życia wpisane zostały w przejrzysty, binarny układ zagrożeń, patologii związanych $z$ funkcjonowaniem w wielkoprzemysłowym mieście oraz szans wynikających z zamieszkiwania $\mathrm{w}$ Łodzi. Jedne i drugie składały się na całość obrazu życia łodzianek. Obrazu złożonego, zbudowanego z konglomeratu różnych warstw społecznych i narodowości. Tworzyły one barwny wizerunek miasta, któremu - w metaforycznym ujęciu - bliżej było do naturalizmu niż sielankowego pejzażu. Kobiety, które nie umiały się przystosować do twardego życia łódzkiego, zbyt ograniczone w swoich możliwościach - prawem, konwenansami społecznymi, zarobkami, rodzina, analfabetyzmem czy, ryzykując pewne uproszczenie, warstwa, $z$ jakiej się wywodziły - miały $\dot{z} y-$ wot naznaczony wieloma przykrościami i trudnościami. Natomiast te wykształcone, majace koneksje rodzinne czy też dar do zarabiania pieniędzy, uczestniczące $\mathrm{w}$ życiu społecznym, niosace pomoc innym, pomimo zmagań $z$ codziennymi problemami, miały szansę na osiagnięcie poczucia spełnienia i zadowolenia $z$ życia $\mathrm{w}$ mieście tysiąca kominów.

\section{Bibliografia}

Kusiak Alicja, O historii kobiet [w:] Humanistyka i pleć. Kobiety w poznaniu naukowym wczoraj i dziś, red. Elżbieta Pakszys, Danuta Sobczyńska, Poznań : Wydawnictwo Naukowe Uniwersytetu im. Adama Mickiewicza w Poznaniu, 1997, t. 2, s. 197-218.

Myśliński Jerzy, Uwagi o prasie polskiej przełomu XIX i XX wieku jako źródle historycznym, „Rocznik Historii Czasopiśmiennictwa Polskiego” 1974, t. 14, s. 5-25, ISSN 0035-7669. 